\title{
Russian science gets caught up in struggles over political reform
}

Moscow. The Russian president, Boris Yeltsin, has written to the Minister of Science, Boris Saltykov, and the president of the Russian Academy of Sciences (RAS), Yury Osipov, demanding proposals from them for a radical reorganization in the way that Russian science is organized. They have been given a month to reply.

In particular, Yeltsin has asked for suggestions about ways of funding individual scientists on a competitive basis. "The country is not able to finance nonproductive scientific research", said Yeltsin in his letter. "It is necessary to find new approaches to financing scientific research within a market economy, and to supporting those scientific centres that are concentrating on the key trends in science."

Yeltsin's appeal coincided with a meeting between a group of scientists and the head of the Russian parliament, Ruslan Khasbulatov, at which Khasbulatov -- one of Yeltsin's chief political rivals also spoke of the need for a recovery of science in Russia. He blamed Yeltsin and the government for the current crisis in science, and promised the scientists that the parliament would give them help.

Both politicians appear to have been acting pragmatically. The conflict between them has reached deadlock, and as a result, the two branches of the Russian government are each trying to attract as many supporters as possible.

This situation has made the scientific community an attractive target. The evaporation of research funds, the temporary closure of many research institutes, and a failure to pay salaries that are already pitifully small have persuaded many scientists to reconsider their previous support of the government, and to look closely at the difficulties of bringing democratic reforms to life. In turn, the politicians now trying to carry through these reforms are worried about losing the backing of the Russian scientists, who have until now been among their most active supporters.

Yeltsin appears genuine in his desire to preserve the scientific potential that still remains in Russia. And the text of his letter reflects suggestions that scientists themselves put forward at a conference organized two years ago by the academy.

At the time, their suggestions were rejected by the academy, which continued to turn for support to the structures and procedures that had previously existed for financing scientific research in the Soviet Union.

As yet, there has been no official re-

sponse to Yeltsin's letter from either the academy or the ministry. However, according to one informed source, its contents have been discussed at a closed meeting of the presidium of the academy, where it was interpreted as a direct attack.

The letter has already aggravated tension between the academy and the Ministry of Science. The two were already in open conflict after the dismissal of Andrei Gonchar, vice-president of the academy,

\section{IMAGE UNAVAILABLE FOR COPYRIGHT REASONS}

Minister of Science.

Fonotov points out that the Russian Foundation of Basic Research was created at the initiative of the ministry, as was a system of scientific centres. "We first stated long ago the need of making serious organizational changes within the management of Russian science. There is nothing that we will have to correct in connection with the President's letter."

In addition, the ministry recently announced plans for creating a new institute of "state professors", a

suggestion made by a number of Russian academicians. A scientist awarded such status will receive a stipend of about $\$ 1,000$ a month a large amount by Russian standards - and other benefits are likely to be introduced.

The status of a state professor will be awarded only to scientists who have been recognized as "outstanding". The ministry estimates that up to 5,000 such appointments will be made. This implies the crea-

from his position as president of the Russian Foundation of Basic Research.

The academy's academic secretary, Igor Makarov, has claimed that the Ministry of Science was responsible for drafting Yeltsin's letter, with the intention of destroying the system of academy institutes. The academy's president, Yury Osipov, has reacted more calmly; he told members of the presidium that, as far as he was aware, the ministry was not involved, and the letter was prepared at the initiative of one of the president's advisers.

Whatever its origins, the Ministry of Science has, in contrast to the academy, reacted to the letter with satisfaction. "We have been following for a long time the scientific and technical policy now being demanded by the President of Russia," says Andrei Fonotov, the First Deputy ton of another state foundation with a yearly budget of US\$50-\$60 million.

The effect of Yeltsin's letter remains unclear. However sensible the scientific and technical policy followed by the ministry, it is unlikely to prevent the rapid collapse of Russian science if the government continues its financing in the same meagre and irregular manner as it has done this summer.

The Ministry of Economics has now paid money whose absence caused a storm of outrage in July in the scientific community. But it not yet come up with any money towards the scientific budget for the second half of the year.

Vladimir Pokrovsky

As Nature went to press, we learnt that President Yeltsin has issued a decree giving urgent help to Russian science. Details will be published in next week's issue.

\section{Concern raised over Warren Spring move}

London. British scientists opposing the plans by the Department of Trade and Industry to merge its Warren Spring Laboratory, one of the country's main centres for research into environmental technology, with AGA Technology, have received backing for their concerns about the government's action from the Royal Commission on Environmental Pollution.

In a letter sent to the department last week, Sir John Houghton, chairman of the commission and a former head of the Meteorological Office, asks for reassurance from the government that the merger of the laboratories will create a national organization "which can quickly achieve a high reputation for expertise and impartiality."

Sir John also emphasizes that the new joint organization, to be known as the National Environmental Technology Centre, should not only take over key staff from Warren Spring but retain and develop some of that laboratory's key characteristics. The staff have claimed that the high number of scientists reluctant to move will make this difficult to achieve. 